\section{AB0975 INCIDENCE OF INFECTIONS WITH BIOLOGICAL THERAPIES IN PARAGUAYAN CHILDREN WITH JUVENILE IDIOPATHIC ARTHRITIS: BIOBADAGUAY (BIOLOGICAL THERAPIES ADVERSE EVENTS PARAGUAYAN-URUGUAYAN REGISTER)}

Z. Morel ${ }^{1,2}$, P. De Abreu $^{3}$, I. Acosta ${ }^{3}$, G. Avila ${ }^{4}$, S. Cabrera ${ }^{4}$ on behalf of BIOBADAGUAY Group. ${ }^{1}$ Cátedra de Pediatría, Universidad Nacional de Asunción; ${ }^{2}$ Pediatría, Hospital Central del IPS; ${ }^{3}$ Sociedad Paraguaya de Reumatología; ${ }^{4}$ Hospital Central del IPS, Asunción, Paraguay

Background: Biological Therapies (BT) are important in the therapeutic arsenal of rheumatic diseases; however there is an increased risk of infections with their use.

Objectives: To determine the frequency and type of infections in Paraguayan patients with Juvenile Idiopathic Arthritis (JIA), included in the BIOBADAGUAY Register.

Methods: A prospective observational study of patients with JIA treated with $B T$, included in the BIOBADAGUAY Register. Patients at the onset of BT were included. The change and/or discontinuation of $B T$ and the occurrence of adverse events (AEs) were recorded. Infectious events as affected organ, type, severity, outcome and need of temporary or permanent suspension of the biological agent were analyzed.

Results: 59 patients with JIA and 69 BT were identified between May 2012 and December 2016. Female: 63\% (37), Men: 37\% (22). The mean age was 10 (3-18) years old. Mean disease progression of $2.8(0.2-12)$ years from the diagnosis to BT beginning. JIA subtypes: poliarticular negative RF $(27 \%)$, oligoarticular $(27 \%$ : extended $22 \%$ and persistent $5 \%$ ), enthesitis related arthritis $(21 \%)$, systemic $(12 \%)$, poliarticular positive RF $(7 \%)$, psoriatic $(3 \%)$, other (indeterminate) $(3 \%)$. Biologic treatments: Adalimumab (ADM) $41(59 \%)$, Etanercept (ETN) $19(28 \%)$, Tolicizumab (TCZ) $9(13 \%)$. There were 83 AEs of all treatments, $80(96 \%)$ no serious and $3(4 \%)$ severe with 1 death. Infections and infestations $54(65 \%)$ of AEs were recorded. Of all TB infections: the $94 \%$ (51) were not serious and the $63 \%$ (34) required temporal discontinuation. Most infectious recovered without sequelae, except one death due to pneumonia (Table 1).

\begin{tabular}{|c|c|c|c|c|}
\hline Type & Number AA & Agent & Suspension & Complete recovered \\
\hline $\begin{array}{l}\text { Respiratory Infection } \\
\text { Infection }\end{array}$ & 33 & $\begin{array}{c}18 \text { ADM } \\
9 \text { ETN } \\
6 \mathrm{TCZ}\end{array}$ & 21 Temporal & Yes \\
\hline & 1 & $1 \mathrm{TCZ}$ & Yes & No (Death) \\
\hline Pulmonary Tuberculosis & 1 & $1 \mathrm{ETN}$ & 1 Temporal & Yes \\
\hline Dengue & 3 & $\begin{array}{l}2 \text { ADM } \\
1 \text { ETN }\end{array}$ & 3 Temporal & Yes \\
\hline Infectious Diarrea & 3 & $\begin{array}{l}1 \mathrm{ADM} \\
1 \mathrm{TCZ} \\
1 \mathrm{TCZ}\end{array}$ & 3 Temporal & Yes \\
\hline Urinary Infection & 2 & $\begin{array}{l}1 \text { ETN } \\
1 \text { ADM }\end{array}$ & 2 Temporal & Yes \\
\hline Chickenpox & 1 & $1 \mathrm{ADM}$ & Temporal & Yes \\
\hline Herpes & 2 & 2 ADM & No & Yes \\
\hline Toxoplasmosis & 1 & $1 \mathrm{ADM}$ & 1 Temporal & Yes \\
\hline Vulvovaginitis & 1 & $1 \mathrm{ADM}$ & No & Yes \\
\hline Skin Infection & 5 & $\begin{array}{l}1 \text { ADM } \\
3 \text { ETN } \\
1 \text { TCZ }\end{array}$ & 2 Temporal & Yes \\
\hline Scabies & 1 & $1 \mathrm{TCZ}$ & No & Yes \\
\hline Total & 54 & $\begin{array}{l}28 \text { ADM } \\
16 \text { ETN } \\
10 \text { TCZ }\end{array}$ & 34 Temporal & \\
\hline
\end{tabular}

Conclusions: 1) Infections and infestations (65\%) were the AEs more frequently observed. 2) Of al Infections, respiratory tract iwere the most frequently observed. 3) Most of the infections were not serious and recovered without sequela. 4) The most frequently agent involved in infectious events was ADM (52\% of all infections); even so it is most frequently administered agent. 5) Increased number of patients, greater diversity of treatment as well as a longer data to corroborate the observation period is required.

Disclosure of Interest: None declared

DOI: 10.1136/annrheumdis-2017-eular.3228

\section{Other orphan diseases}

\section{AB0976 REMISSION OF MULTICENTRIC RETICULOHISTIOCYTOSIS WITH COMBINATION TOCILIZUMAB AND ZOLEDRONATE}

A. Gough ${ }^{1}$, B. Barber ${ }^{2}$, H. Evennett ${ }^{3}$, S. Hern ${ }^{4}$, M. Lloyd ${ }^{1} .{ }^{1}$ Rheumatology; ${ }^{2}$ Radiology; ${ }^{3}$ Dermatology, Frimley Park Hospital, Frimley; ${ }^{4}$ Dermatology, Spire Clare Park Hospital, Crondall, United Kingdom

Background: Multicentric reticulohistiocytosis $(\mathrm{MRH})$ is a rare non-Langerhans cell histiocytosis. It can affect any organ but predominantly skin and joints. Joint involvement usually precedes skin involvement and can be very destructive. Early diagnosis and treatment is therefore important but can be difficult.We describe a woman with $\mathrm{MRH}$ and severe erosive joint disease who responded to combination tocilizumab and zoledronate.
Objectives: A 43 yr old woman presented in 2012 with a 3 mth history of rash on her face, chest and ears and fingers, and arthralgia affecting shoulders, wrists, fingers and knees. On examination she had diffuse hand swelling, right knee effusion and erythematous eruption affecting her face, chest and ears with papules on the sides of her fingers.

Investigations: normal FBC, CRP, U+Es, LFTs. ESR $12 \mathrm{~mm} / \mathrm{hr}$. ANA +ve at 1:1280 (finely speckled). Ro +ve; ENA including Jo-1, ANCA and dsDNA antibodies -ve, C3/4, Igs all normal/-ve. Hand XR: periarticular DIP erosions. Skin biopsy: large multinucleate cells with abundant cytoplasm staining positive with CD68 (histiocytic marker); CD1a negative (Langerhans cell marker), consistent with MRH. PET-CT body: incidental finding of thymic remnant.

Methods: Initial Rx:prednisolone $20 \mathrm{mg}$ od + HCQ 200mg bd with initial good response of joint and skin symptoms, but recurrence of symptoms on reducing steroid dose. Nov 2012: MTX up to $20 \mathrm{mg} /$ week added. Stopped after $4 \mathrm{mths}$ because of a linear rise in P3NP levels to 11.2. Fibroscan showed slightly raised stiffness of $7.4 \mathrm{kPa}$. AZA 75mg od introduced in Feb 2013, then etanercept $50 \mathrm{mg}$ weekly. This led to good control of symptoms for approximately $4 \mathrm{mths}$ on single agent therapy. March 2014: relapse of joint and skin symptoms. June 2014: tocilizumab $8 \mathrm{mg} / \mathrm{kg}$ iv 4 weekly started. After 5 infusions, her skin cleared for the first time. December 2014: relapse of joint and skin symptoms. Tocilizumab was adjusted to $650 \mathrm{mg}$ per mth from $620 \mathrm{mg}$ in view of slight weight gain. Annual iv zoledronate $5 \mathrm{mg}$ was started. She has had no further joint or skin exacerbations. July 2015: prednisolone was down to $1 \mathrm{mg}$ daily and stopped completely by May 2016. From July 2015 there appears to have been no progression in DIP joint erosions, and possibly some healing of the DIP changes. She has remained off any steroids.

Results: Picture shows X ray hands July 2015

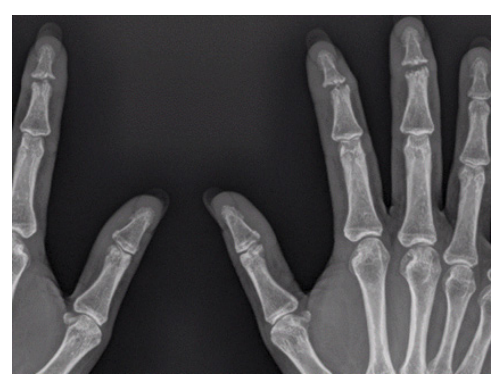

Conclusions: The pathogenesis of MRH is poorly understood. The overexpression of cytokines including TNF $\alpha, \mathrm{IL}-1$ and IL- 6 in inflammatory lesions gives a number of logical drug options, including tocilizumab. The observation that mononuclear cells in both skin nodules and synovium in MRH exhibit some properties of osteoclasts might explain the mechanism behind reported success using bisphosphonates. To our knowledge, this is only the second case to report success with using tocilizumab in the treatment of $\mathrm{MRH}$ and the first to report on concomitant treatment with a bisphosphonate. No adverse effects have been observed throughout treatment, and remission appears to be sustained. Without withdrawing treatment we cannot know if the remission is natural or drug induced, though the relatively short timescale suggests a drug effect.

Disclosure of Interest: None declared DOI: 10.1136/annrheumdis-2017-eular.4488

\section{AB0977 DETERMINATION OF A CUT-POINT BETWEEN LOW/HIGH ANTI RNP ANTIBODIES TITRES, IN PATIENTS WITH MIXED CONNECTIVE TISSUE DISEASE}

D.A. Botello Corzo ${ }^{1}$, C. Bouroncle Alaluna ${ }^{1}$, C. De la Puente Bujidos ${ }^{1}$,

A. Boteanu ${ }^{1}$, G. Roy Ariño ${ }^{2} .{ }^{1}$ Rheumatology; ${ }^{2}$ Immunology, Hospital Ramón y Cajal, Madrid, Spain

Background: Sharp described Mixed Connective Tissue Disease (MCTD) in $1972^{1}$. MCTD is characterised by the presence of Raynaud phenomenon, puffy hands, synovitis, acrosclerosis, myositis and positive anti-ribonucleoprotein (RNP) antibodies. Classification criteria for MCTD except for Kasukawa's criteria demand the presence of high titres of anti-RNP antibodies (measured by hemagglutination). As a result, the cut-point between low and high anti-RNP titres must be well defined. In best of our knowledge, this cut-point have not been established for modern laboratory techniques.

Objectives: Determinate a cut-point between low/high anti-RNP titles measured by ELISA, for the diagnosis of Mixed Connective Tissue disease. Describe the clinical and immunological characteristics of patients with positive titres of anti-RNP antibodies.

Methods: It was a Retrospective cohort study of patients with positive anti-RNP antibodies $(>10)$ measured by ELISA. We had identified all patients with positive antiRNP antibodies titres in the last five years, using our laboratory base date. Clinical histories were reviewed, we recollected clinical and paraclinical data. We performed descriptive analysis and ROC curves for diagnostic tests with STATA software.

Results: We detected 75 patients with positive antiRNP antibodies, we obtained 65 clinical records. $89,23 \%$ (58) of patients were women and $10,77 \%$ (7) men. 